\title{
The Rare Earths in Modern Science and Technology
}

Volume 3 


\section{The Rare Earths}
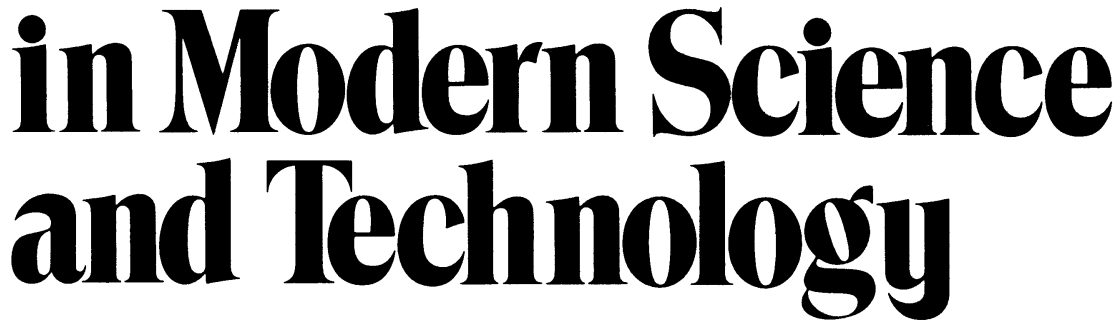

Volume 3

Edited by

Gregory J. McCarthy

North Dakota State University, Fargo, North Dakota

\section{Herbert B. Silber}

University of Texas at San Antonio, San Antonio, Texas

and

James J. Rhyne

National Bureau of Standards, Washington, D.C.

Associate Editor

Faye M. Kalina

North Dakota State University, Fargo, North Dakota

Editorial Assistants

Linda R. Haugrud and Joyce L. Mortensen

North Dakota State University, Fargo, North Dakota 


\section{Library of Congress Cataloging in Publication Data}

Rare Earth Research Conference.

The rare earths in modern science and technology.

Vol. 3- edited by G. J. McCarthy, H. B. Silber, and J. J. Rhyne.

Includes bibliographical references and indexes.

1. Earths, Rare-Congresses. I. McCarthy, Gregory J. II. Rhyne, J. J. III. Silber, Herbert B.

QD172.R2R27 1978

ISBN-13: 978-1-4613-3408-8

DOI: 10.1007/978-1-4613-3406-4

Proceedings of the 15th Rare Earths Research Conference, held June 15-18, 1981, at the University of Missouri at Rolla

\section{1982 Plenum Press, New York}

Softcover reprint of the hardcover 1st edition 1982

A Division of Plenum Publishing Corporation

233 Spring Street, New York, N.Y. 10013

All rights reserved

No part of this book may be reproduced, stored in a retrieval system, or transmitted in any form or by any means, electronic, mechanical, photocopying, microfilming, recording, or otherwise, without written permission from the Publisher 
FOREWORD

The Fifteenth Rare Earth Research Conference was held June 15-18, 1981 on the Rolla campus of the University of Missouri. The conference was hosted by the Graduate Center for Materials Research, the College of Arts and Science, and the School of Mines and Metallurgy.

It was expected that the conference would provide a forum for critical examination and review of the current and important trends in rare earth science and technology. To this end, over 170 papers were presented in both oral and poster sessions by researchers representing some nineteen countries. The program committee was particularly gratified to see the diversity of effort being devoted to rare earth research by different disciplines all over the world. The collection of refereed papers in this volume attests to the fact that the objectives of the program committee were indeed realized.

A high point of the meeting was the presentation of the Frank H. Spedding Award to a most distinguished colleague, Professor Georg Busch, Eidgenossische Technische Hochschule, Zurich. Professor W. Edward Wallace, University of Pittsburgh, recipient of the first Frank $\mathrm{H}$. Spedding Award made the presentation to Professor Busch who then gave the Plenary Address.

Oral sessions began with keynote addresses delivered by: B.D. Sykes, University of Alberta; J.E. Greedan, Mclłaster University; M. Tecotzky, U.S.R. Chemicals; J.R. Jackman, Reactive Metals and Alloys; J. Owens, Harshaw Chemical; W.T. Carna11, Argonne National Laboratory; M.B. Maples, University of California-San Diego; R. Lemaire, Neel Laboratory, Grenoble, France; W.J. Evans, University of Chicago; E. Kaldis, ETH, Zurich, Switzerland; R.G. Barnes, Iowa State University; and P. Muntz, Universitat Konstanz/FRG.

The success of any scientific meeting depends largely upon the voluntary efforts of many dedicated people. I first wish to 
acknowledge with much appreciation the advice and assistance given me upon assuming my duties as president of the board and conference chairman by the past conference chairman and secretary, Professor John Gruber and Faye Kalina.

The success of the program is testimony to the talents of Professor Gregory Choppin and the excellent job done by his program committee and session chairpersons.

\section{Program Committee}
G. Barlow
R. Haire
H. Silber
E. Greedan
J. Kaczmarec
S. Taher
K. Gschneidner
H. Marks
A. Tauber

Session Chairpersons

$\begin{array}{ll}\text { J.C. Achard } & \text { F.L. Carter } \\ \text { J.L. Atwood } & \text { W.T. Carnall } \\ \text { E. Banks } & \text { J. Chrysochoos } \\ \text { B.J. Beaudry } & \text { J. Deportes } \\ \text { B.A. Bilal } & \text { T. Donahue } \\ \text { J-C. Bunzli } & \text { L. Eyring } \\ \text { O.N. Carlson } & \text { J. Gruber } \\ \text { P. Caro } & \text { K. Gschneidner } \\ \text { A. Percheron-Guegan } & \text { O. Serra } \\ \text { R.G. Haire } & \text { A. Dean Sherry } \\ \text { J.M. Haschke } & \text { S.M.A. Taher } \\ \text { J. Kaczmarec } & \text { W.E. Wallace } \\ \text { H. Kirchmayr } & \text { G. Gor1ler-Walrand } \\ \text { S.K. Malik } & \text { W.C. Weimer } \\ \text { T.J. Marks } & \text { W. Yelon } \\ \text { L. Niinisto } & \end{array}$

I appreciate the many hours of work contributed by those who served on the following committees:

\section{Loca1 Committee}

Adrian Daane, Chairperson

Harlan Anderson

Gordon Lewis

Thomas O'Keefe

D. Vincent Roach

Donald Sparlin

Manfred Wuttig

William Yelon
Selection Committee for the

Frank H. Spedding Award Recipient

W.E. Wallace, Chairperson

Joseph Cannon

Paul Caro

J.B. Gruber

Fred Rothwarf 
Arlene James, Chairperson

Jean Daane

Eunice French

We are all deeply indebted to the co-editors of the Conference Proceedings who gave many hours to the organization and refereeing of the papers in bringing you Volume 3 of "The Rare Earths in Modern Science and Technology".

We are also very appreciative of the monetary support provided to the Conference by the following donors:

National Science Foundation, Washington, D.C., U.S.A.

Petroleum Research Fund (American Chemical Society), Washington, D.C., U.S.A.

Modern Metals, Union/Molycorp, Los Angeles, California, U.S.A.

Raytheon Corp., Lexington, Massachusetts, U.S.A.

Reactive Metals and Alloys Corp., West Pittsburgh, Pennsylvania, U.S.A.

Rhone-Poulenc Industries (Chimie Fine Division), Paris, Cedex 08, France

Ronson Metals Corp., Newark, New Jersey, U.S.A.

University of Missouri-Rolla, Rolla, Missouri, U.S.A.

North Dakota State University, Fargo, North Dakota, U.S.A.

I must acknowledge, especially, the invaluable help and counsel of Norma Fleming, Conference Coordinator, and her staff, and of Professor Adrian Daane, Chairman of the Local Committee.

I thank very much our secretaries: Faye Kalina for assisting the co-editors with the manuscripts and proceedings, Janet Thompson and Nina Haas, Materials Research, UMR, for assisting with all phases of the Conference activities; Jane Bunting and Audrey Thompson, Extension Office, UMR, for handling mailings and registration; and Gislaine Meneroud, Neel Laboratory, Grenoble, for assisting with registration.

Last1y, I wish to thank all the conference participants for their kindness and congeniality. I look forward to seeing all of you again at the Sixteenth Rare Earth Research Conference at Florida State University in April 1983.

William J. James

General Conference Chairman University of Missouri-Rolla November 1981 


\section{PREFACE}

A coherent picture of research progress and new developments involving the rare earths can be difficult to develop due to the wide dispersal of relevant papers throughout the physics, chemistry and materials literature. We have once again taken advantage of the international gathering of scientists for a Rare Earth Research Conference to present under one cover a comprehensive update of the rare earths in modern science and technology. Authors presenting papers in Rolla were invited to submit papers or notes for this volume. All submissions were refereed. We have included three types of contributions: 1onger invited review papers, shorter research reports and one or two page notes. The first two are meant to have this volume as their sole publication outlet while the notes are typically from authors who have submitted, or are planning, a full publication elsewhere.

Among the 120 contributions in this volume the reader will find many papers in two of the areas where rare earths have been utilized most heavily over the last two decades, luminescent and magnetic materials. Professor Busch's Spedding Award Address describes the pioneering work of his group at the ETH, Zurich, on such materials and provides us with historical insight into research on the rare earths when their complex electronic structure, spectra and interactions in solids were just beginning to be understood. The role of rare earths in steelmaking is also reviewed. This volume also has strong components in the physical and structural chemistry of rare earth compounds and in the innovative applications of rare earths in bioinorganic, organometallic and coordination chemistry. We also welcome our first contributions from scientists in the People's Republic of China.

H.B. Silber, J.J. Rhyne and I would especially like to acknowledge the many referees whose efforts contributed so much to the quality of this volume.

Gregory J. McCarthy Fargo, North Dakota October, 1981 
Presentation of the Frank H. Spedding Award for Outstanding Contributions to the Science and Technology of the Rare Earths to Professor Georg Busch

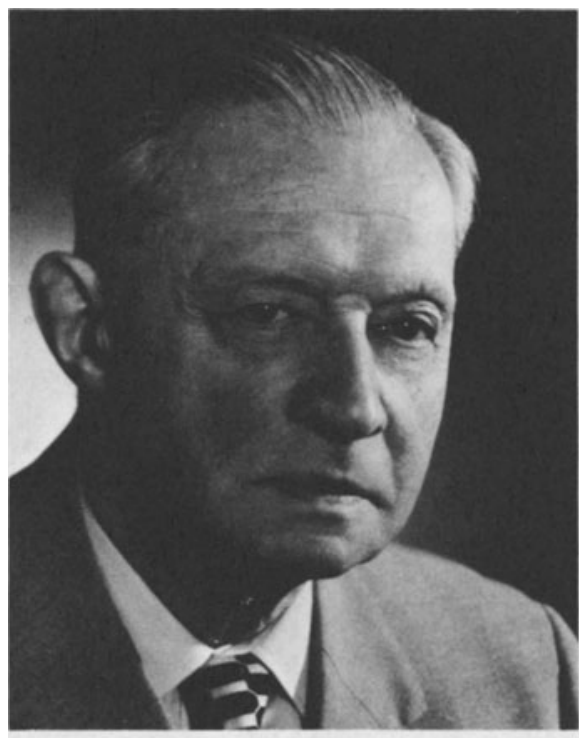

GEORG BUSCH

Our Spedding Award recipient has had a scientific career of almost incredible depth and range. Prof. Busch's early interests lay with the phenomenon of ferroelectricity. In that, he had interests in common with the late Prof. Berndt Matthias, whose origin was also in the Eidgenössische Technische Hochschule Zurich.

Prof. Busch became interested in the 1940's in semiconductor physics and in the early 1950's he began a search for a ferromagnetic semiconductor. In time he realized that his great quest led 
inexorably to the rare earths. (My feeling is that when you need a certain material property you can nearly always find it among the rare earth systems.) In his studies of rare earth-containing III-V semiconductors, such as GdN and CeP, and II-VI semiconductors, such as EuS and TmS, he found his ferromagnetic superconductor.

In his work on the rare earth chalcogenides and pnictides he wrote a new chapter in the solid state sciences. Recognizing the importance of chemical control, Prof. Busch established a Solid State Chemistry Group within his Solid State Physics Institute and they produced and studied in great depth single crystals of the rare earth pnictides and chalcogenides which had been characterized in the most exhaustive detail.

His work of the 60's and 70's involved synthesis and studies of the structural, thermodynamic, magnetic and optical properties of this large class of inorganic compounds. Prof. Busch's work involved classical studies such as determination of specific heats and bulk magnetization but also involved more recently introduced techniques such as ESR, XPS and spin-polarized photoemission. The latter is, I believe, a first in Prof. Busch's laboratory. If you wish to know all about his rare earth chalcogenide and rare earth pnictide work, then you have the job of reading about 110 papers which he has published on these materials.

Recently his attention has turned to intermetallic hydrides -hydrogen storage systems -- structures of complex hydrides and surface features. In the early $1960^{\prime}$ s our group in Pittsburgh began work on rare earth nitrides. We soon encountered the stunningly brilliant work of Busch and Vogt on rare earth nitrides. And we decided upon other things to do. In our work on hydrides we recognize Busch's group at Zurich as a force to be reckoned with. Or to put it in less pejorative language, the Zurich group under Busch is a world center of excellence in hydride research. And from this excellence I am convinced all the world will profit.

It is a very great pleasure for me to present Prof. G. Busch, the 1982 Spedding Award recipient.

\author{
W. E. Wallace \\ University of Pittsburgh \\ June, 1981
}




\section{CONTENTS}

\section{SPEDDING AWARD ADDRESS}

Rare Earth Reminiscences . . . . . . . . . . . . . 1

\section{BIOINORGANIC CHEMISTRY}

Magnetic Resonance Studies of Metal Cation Transport Across Biological Membranes: Use of Paramagnetic Lanthanide Ions . . . . . . . . . 15

J.A. Balschi, V.P. Cirillo, W.J. leNoble, M.M. Pike, E.C. Schreiber, Jr., S.R. Simon and C.S. Springer, Jr.

Inter-Lanthanide Ion Energy Transfer Distance Measurements in Biological Systems . . . . . . . . . 21 W. DeW. Horrocks, Jr., M.-J. Rhee, A.P. Snyder, T. Choosri, and V.K. Arkle

Gadolinium as an EPR and NMR Probe of $\mathrm{Ca}^{2+}$ Sites in Biological Systems . . . . . . . . . . . 25

E.M. Stephens and C.M. Grisham

Optical Activity of Mixed-Ligand Complexes of $\mathrm{Tb}$ (III) with Pyridine-2,6-Dicarboxylic Acid and Hydroxycarboxylic Acids . . . . . . . . . . 31 H.G. Brittain

Terbium Luminescence as a Probe of Lanthanide Coordination in Solution . . . . . . . . . . . . 35 F.S. Richardson

A ${ }^{160} \mathrm{~Tb}$ (III) Probe of the Calcium Binding Sites of Muscle Calcium Binding Parvalbumin . . . . . . . . 37

F. Gonzalez-Fernandez and D.J. Nelson 
The Lanthanides as Structural Probes in Peptides . . . . . . 45

R.E. Lenkinski, and R.L. Stephens

Multinuclear NMR Study of Three Aqueous Lanthanide Shift

Reagents: Complexes with EDTA and Two Macrocyclic

Ligands . . . . . . . . . . . . . . . 53

C.C. Bryden, C.N. Reilley and J.F. Desreux

Structures of Dithiophosphinate Complexes of the Lanthanides

in the Solid and Solution by X-Ray Diffraction and

Paramagnetic NMR . . . . . . . . . . . 59

A. A. Pinkerton

\section{ORGANOMETALLIC AND COORDINATION CHEMISTRY}

Recent Advances in the Low Valent Approach to f-Element

Organometallic Chemistry .. . . . . . . . 61

W.J. Evans

Laser Photochemistry of a Uranium Compound Tailored for 10 $\mu$ Absorption: $\mathrm{U}\left(\mathrm{OCH}_{3}\right)_{6}$. . . . . . . . . . . 71

E.A. Cuellar, S.S. Miller, R.C. Teitelbaum, T.J. Marks, and E. Weitz

New Stoichiometric and Catalytic Pentamethylcyclopentadienyl

Organoactinide Chemistry . . . . . . . . . . 77

P.J. Fagan, E.A. Maatta, A.M. Seyam, and T.J. Marks

Choosing a Coordination Number for Ln(III): $1: 1,1: 2,2: 1,3: 2$ and 4:3 Complexes with Crown Ethers . . . . . . . 85

J.-C.G. Bünzli, D. Wessner, A. Giorgetti and Y. Frésart

A Systematic Study of the Complexation of DI- and TRI-Valent Lanthanide Ions by Macrocycles of Varying Size . . . 87

J.F. Desreux and J. Massaux

Octahedral Compounds of Lanthanides: Trimethylphosphine Oxide (tmpo) as Ligand . . . . . . . . . . . . 91 0. A. Serra and M. Moraes

Amine Complexes of Divalent Europium . . . . . . . . . . 95 F.A. Hart, and W. Zhu

High Coordination Polyhedra of Trivalent Rare Earth Ions • • 97 J.-C.G. Bünzli, and B. Klein 
Erbium Chloride Complexation in Aqueous DMF . . . . . . . . 99

H.B. Silber, and M.R. Riddle

Lanthanide Hexafluoroantimonate Complexes

of Hexamethylphosphoramide . . . . . . . . . . 105

S.M. Melo and N.M.P.S. Ricardo

\section{SPECTROSCOPY}

Parametrisation of the MCD-Spectra of Rare Earths:

Example of $\mathrm{Pr}^{3+}$ in PVA-Matrix . . . . . . . . . 109

C. Görller-Walrand, N. De Moitié-Neyt, and $\mathrm{Y}$. Beyens

Ab-Initio Calculation of Lanthanide Crystal Field

Parameters and Transition Probabilities . . . . . . 115

M. Faucher and 0. Malta

On the Origin of Resonance Lines in 3d Emission

Spectra of Rare Earths . . . . . . . . . . . 121

J. Kanski

Transition Intensities for $\mathrm{Nd}^{3+}$ in Crystals . . . . . . . . 125

A.A.S. da Gama and G.F. de Sá

Truncation Effects on Crystal Field Calculations for

the $4 \mathrm{f}^{6}\left(\mathrm{Eu}^{3+}\right)$ Configuration in Solids . . . . . . 127

G.T. de Sagey, P. Porcher, G. Garon and P. Caro

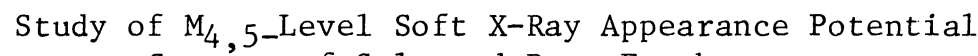

Spectra of Selected Rare Earths . . . . . . . . . 131

D. Chopra and G. Martin

The Effect of Multiplet Splitting of the 4d Levels

in Rare Earth Elements on Their X-Ray Spectra . . . . 135

S.I. Salem

Optical Spectra, Energy Levels, and Crystal-Field Analysis of Tripositive Rare Earth Ions in

$\mathrm{Y}_{2} \mathrm{O}_{3}$ : I. Kramers Ions in $\mathrm{C}_{2}$ Sites . . . . . . . . . 139

N.C. Chang, J.B. Gruber, R.P. Leavitt, and C.A. Morrison

$\mathrm{Sm}^{2+}$ Activated Mixed Fluorides: Synthesis and Fluorescence . . . . . . . . . . . . . . 143

F. Gaume, A. Gros and J.C. Bourcet

Electric and Magnetic Dipole Strengths of $f-f$

Transitions in Cubic $\mathrm{Cs}_{2} \mathrm{NaYCl}_{6}: \mathrm{Ln}^{3+}$ Systems . . . . . 147

F.S. Richardson 
Absorption Spectrophotometric Characterization of $\operatorname{Sm}(I I), \operatorname{Sm}(I I I)$, and $\operatorname{Sm}($ II/III) Bromides and Sm(III) Oxybromide in the Solid State . . . . . .

A.B. Wood, J.P. Young, J.R. Peterson and J.M. Haschke

Cascade Laser Action in $\mathrm{Tm}^{3+}$ :YLF . . . . . . . . . . . . .

L. Esterowitz, R. Allen and R. Eckardt

Laser Induced Luminescence of $\mathrm{Pr}^{3+}$ in $\mathrm{CaF}_{2}$ Attributed to Different Local Site Symmetries . . . . . . . .

J. Chrysochoos, J.M. Stillman and P.W.M. Jacobs

Photoconductivity Due to Autoionization of Divalent Rare Earth Impurities in Crystals Having the Fluorite Structure . . . . . . . . . . . . .

C. Pedrini, F. Gaume-Mahn and D.S. McClure

The Effect of Structural Environment on the Absorption

Spectra of Selected Lanthanide Sesquioxides . . . .

R.G. Haire, J.P. Young and J.R. Peterson

The $\mathrm{Ce}^{3+} \rightarrow \mathrm{Tb}^{3+}$ Transfer in Phosphate Host Lattices . . . .

P. Bochu, C. Parent, A. Daoudi, G. Le Flem and P. Hagenmuller

Laser Excited Luminescence of $\mathrm{Tb}^{3+}, \mathrm{Eu}^{3+}$-Activated

Ferroelectric Gadolinium Molybdate (GMO)

B.K. Chandrasekhar and W.B. White

Luminescence of High-Pressure Phases of $\mathrm{Eu}^{2+}$ Activated

Alkaline Earth Borates and Silicates . . . . . . .

G. Adachi, K. Machida and J. Shiokawa

PMR Spectroscopic Studies of Lanthanide Aminocarboxylate

Complexes . . . . . . . . . . . . . . . .

G.R. Choppin, P.A. Baisden and E.N. Rizkalla

The Interaction of $1: 1$ and $1: 2$ Lanthanids-EDTA

Chelates with Alkali Cations: Aqueous

Relaxation Reagents for Metal Nuclide NMR . . . .

G.A. Elgavish

Luminescence of L-(-)-Tryptophan in DMSO at $77 \mathrm{~K}$ in

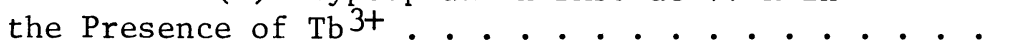

$\mathrm{V}$. Anantharaman and $\mathrm{J}$. Chrysochoos

Hypersensitivity in the $4 f-4 f$ Absorption Spectra of $\mathrm{Er}^{3-}$ and $\mathrm{Ho}^{3+}$ Complexes ...............

S.A. Davis and F.S. Richardson 
Possible Symmetries of the Coordination Sphere of $\mathrm{Eu}^{3+}$ in DMSO via a Correlation of Magnetic Circular Dichroism (MCD) with Absorption and Emission Spectra ..................

J. Chrysochoos, M.J. Stillman and P.W.M. Jacobs

Dipheny1-Phosphiny1-Morpholide (DPPM) Lanthanide Salt Adducts: $\mathrm{Nd}^{3+}$ and $\mathrm{Eu}^{3+}$ Spectra . . . . . .

G. Vicentini and L.R.F. Carvalho

Adducts of Lanthanide Trifluoromethanesulfonates and Tetramethylene Sulfoxide (TMSO) . . . . . . . .

L.B. Zinner and F.A. Araujo

Photoreduction of Ytterbium and Samarium . . . . . . . .

T. Donohue

\section{PHASE EQUILIBRIA AND THERMODYNAMICS}

CeN: Phase Relationships and Enthalpies of Solution . . . 227

E. Kaldis, B. Steinmann, B. Fritzler

E. Jilek and A. Wisard

Enthalpies of Solution and Lattice Constant Anomalies of $\mathrm{Sm}_{3} \mathrm{~S}_{4}-\mathrm{Sm}_{2} \mathrm{~S}_{3}$ Solid Solutions . . . . . . . .

E. Kaldis, H. Spychiger, B. Fritzler and E. Jelek

High Temperature Phase Diagram and Enthalpies of Solution of $\mathrm{TmSe}$. . . . . . . . . . . . . . . . . .

B. Fritzler, E. Kaldis and E. Jilek

Densities and Concentration of Defects in TmSe . . . . . .

B. Fritzler, E. Kaldis, B. Steinmann, E. Jilek and A. Wisard

Preparation and Thermoelectric Properties of Some

Rare Earth Chalcogenides . . . . . . . . . . . .

T. Takeshita, B.J. Beaudry and K.A. Gschneidner, Jr.

Thermal Decomposition of Rare Earth Sulfate and

Selenate Hydrates . . . . . . . . . . . . . . . .

L. Niinistö, P. Saikkonen and R. Sonninen

Rare Earth Oxysulfide/Oxysulfate Equilibria at

$1100-1500 \mathrm{~K}$. . . . . . . . . . . . .

R.K. Dwivedi and D.A.R. Kay 
Phase Studies and Selective Oxidation in Rare EarthMolybdenum-Oxide Systems, $\mathrm{Ln}_{2} \mathrm{O}_{3}-\mathrm{MoO}_{2}-\mathrm{MoO}_{3}$

H. Prévost-Czeskleba and G. Tourné

Correlation of Spectral and Heat-Capacity Schottky

Contributions for $\mathrm{Dy}_{2} \mathrm{O}_{3}, \mathrm{Er}_{2} \mathrm{O}_{3}$ and $\mathrm{Yb}_{2} \mathrm{O}_{3}$.......

E.F. Westrum, Jr., R.D. Chirico and J.B. Gruber

Enthalpy of Formation of Barium Lanthanide(IV) Oxides: $\mathrm{BaCeO}_{3}, \mathrm{BaPrO}_{3}$, and $\mathrm{BaTbO}_{3}$. . . . . . . . . .

L.R. Morss and N. Mensi

On Mixed Crystals of $\operatorname{Pr}_{1-y} \mathrm{~Tb}_{y} \mathrm{O}_{\mathrm{x}}$ Grown Under

High Oxygen Pressures . . . . . . . . . . . .

B. Chang, M. McKelvy and L. Eyring

A Kinetic Study of the Oxidation of Zeta Phase

Praseodymium Oxide: $\frac{10}{9} \operatorname{Pr}_{90} \mathrm{O}_{16}+\frac{1}{9} 0_{2} \rightarrow \mathrm{Pr}_{10} \mathrm{O}_{18} \cdot$..

T. Sugihara, S.H. Lin and L. Eyring

Predicted Stabilities of Rare Earth Dihalides . . . . . .

S. Bratsch and H.B. Silber

Vaporization and Thermodynamic Properties of

Samarium Dicarbide and Nonstoichiometric

Disamarium Tricarbide . . . . . . . . . . .

J.M. Haschke and T.A. Deline

Complexity of Phase Equilibria in the MM-Co-Fe System

Between 2:7 and 1:5 Stoichiometries . . . . . . .

E.M.T. Velu, S. Laha, E.C. Subbarao, K.P. Gupta,

A.K. Majumdar, T.A.P. Sankar, S. Pandian

and U. Ramakrishna

Low Temperature-High Magnetic Field Heat Capacity

Studies of Weakly and Nearly Ferromagnetic and

Mixed Valence Rare Earth Materials . . . . . . .

K.A. Gschneidner, Jr., K. Ikeda and O.D. McMasters

\section{STRUCTURAL AND SOLID STATE CHEMISTRY}

Anomalous Behavior of Cerium and Europium Ions

in Ternary Molybdenum Chalcogenides (Chevrel Phases).

301

M.B. Maple, M.S. Torikachvili, R.P. Guertin

and $\mathrm{S}$. Foner

New Fluorides with $\mathrm{Ce}^{\mathrm{IV}}, \operatorname{Pr} \mathrm{IV}, \mathrm{Nd}^{\mathrm{IV}}, \mathrm{Tb}^{\mathrm{IV}}$, and $\mathrm{Dy}^{\mathrm{IV}} . .$. .

R. Hoppe 
Ternary Halides of the Rare Earth Elements:

Phases and Structures . . . . . . . . . . .

G. Meyer

Investigation of the "Diadochic" Incorporation of the Rare Earth Elements in $\mathrm{CaF}_{2}$ at Elevated

Temperature and Pressure . . . . . . . . . . . .

B.A. Bilal, P. Becker, V. Koss and H. Nies

Crystal Structures of $\mathrm{EuMgF}_{4}, \mathrm{SmMgF}_{4}$, and $\mathrm{SrMgF}_{4}$. . . . .

E. Banks, R. Jenkins and B. Post

Structural Phase Transitions in $\mathrm{Cs}_{2} \mathrm{NaLnCl}_{6}$. . . . . . . . .

G.P. Knudsen, F.W. Voss, R. Nevald and H.-D. Amberger

Synthesis and Crystal Data for Alkaline Earth-

Lanthanide Phosphates with the Eulytite Structure . .

G.J. McCarthy, D. Krabbenhoft, R.G. Garvey and C. Roob

The Crystal Structure and Stoichiometry of the

$\mathrm{Ca}_{2+x^{N d}}{ }_{8-x}\left(\mathrm{SiO}_{4}\right)_{60} \mathrm{O}_{2-1 / 2 x}$ System . . . . . . . .

J.A. Fahey and W.J. Weber

Electron Beam-Induced Reduction of $\mathrm{TbO}_{2-\delta}$ : A High

Resolution Electron Microscope Study ... . . . . 345

L. Eyring and R.T. Tuenge

Crystal Structure and Properties of (LaO) CuS and

(LaO)Ags . . . . . . . . . . . . . . . . . .

M. Palazzi, C. Carcaly, P. Laruelle and J. Flahaut

The Crystal Chemistry of the Europium Arsenides . . . . . .

F.L. Carter and L.D. Calvert

Crystal Structures and Phase Relationships within Ternary

Systems: Rare Earth Metal-Noble Metal-Boron . . . .

P. Rogl and H. Nowotny

Fast Diffusion and Electrotransport of Cobalt, Iron and Nickel in $\alpha$-Yttrium . . . . . . . . . . . .

I.C.I. Okafor and O.N. Carlson

Ternary Compounds in $\mathrm{RE}(\mathrm{Au}, \mathrm{Ga})_{2}$ and $\mathrm{RE}(\mathrm{Ag}, \mathrm{Ga})_{2}$ Alloys . . . A.E. Dwight

\section{MAGNETIC PROPERTIES}

Magnetic Properties of $\mathrm{ErM}_{3}, \mathrm{M}=(\mathrm{Ni}, \mathrm{Fe}, \mathrm{Co}) . . . . . . .361$

B. Decrop, J. Deportes, B. Kebe, C. Crowder, W.J. James and W. Yelon 
Transport and Magnetic Properties of the $\mathrm{Gd}_{4}\left(\mathrm{Co}_{1-\mathrm{x}} \mathrm{Ni}_{\mathrm{x}}\right)_{3}$

Series $(0 \leqslant x \leqslant 0.2)$. . . . . . . . . . . . 367

E. Gratz, G. Hilscher, H. Kirchmayr and H. Sassik

Structures and Magnetism of Some Polycomponent 2:7

Rare Earth-Transition Metal Systems . . . . . . . 373

W.E. Wallace, M. Merches and R.S. Craig

Evidence for the Noncollinearity of the Magnetic

Structure of $\mathrm{Er}_{6} \mathrm{Mn}_{23}$. . . . . . . . . . . . . . 377

B. Kebe, C. Crowder, W.J. James, J. Deportes,

R. Lemaire and $W$. Yelon

Mössbauer Investigation of the Effect of Annealing on

the Ordering Temperature of Amorphous $\mathrm{DyFe}_{2}$. . . . . . 381

C. Bucci, E. Bauminger and H. Savage

Magnetization and ${ }^{55} \mathrm{Mn}$ Hyperfine Field in $\mathrm{RMn}_{2}$

$(\mathrm{R}=$ Rare Earth) Intermetallic Compounds . . . . . 385

S.K. Malik, S.K. Dhar, R. Vijayaraghavan,

K. Shimizu and W.E. Wallace

Magnetic Properties of Cubic and Hexagonal HoMn 2 . . . . . 391

J. Rhyne, K. Hardman, S. Malik and W. Wallace

Susceptibility Densities in the Pauli Paramagnets

$\mathrm{YNi}_{5}$ and $\mathrm{CeNi}_{5}$. . . . . . . . . . . . . . . . . . 393

D. Gignoux, D. Givord, F. Givord, R. Lemaire and F. Tasset

Thermal Variation of Anisotropies of Cobalt in YCo5 and $\mathrm{NdCo}_{5}$ Up to $450 \mathrm{~K}$. . . . . . . . . . . . . . . . . 399

J.M. Alameda, D.Givord, R. Lemaire and Q. Lu

The Magnetic Structure of $\mathrm{Y}\left(\mathrm{Mn}_{1-\mathrm{X}} \mathrm{Fe}_{\mathrm{X}}\right)_{12}$. . . . . . . . . . 403

Y.C. Yang, G.J. Long, B. Kebe, W.J. James and J. Deportes

Magnetic Characteristics of the Intermetallic Compounds

$\mathrm{R}_{2} \mathrm{Ni}_{17-\mathrm{X}} \mathrm{Al}_{\mathrm{X}}(\mathrm{R}=\mathrm{Gd}, \mathrm{Tb}) .$. . . . . . . . 407

M. Coldea and I. Pop

Observation of Spiral Spin Antiferromagnetic Domains

in Single Crystal Terbium . . . . . . . . . . 413

S.B. Palmer, J. Baruchel, S. Farrant,

D. Jones and M. Schlenker

Crystal Field and Quadrupolar Effects on the Third-Order Magnetic Susceptibility . . . . . . . . . . 419

P. Morin and D. Schmitt 
Magnetic Properties of Some Single Crystal Rare Earth Tetraborides . . . . . . . . . . . . . .

J. Etourneau, B. Chevalier, R. Georges, G. Will, W. Schäffer and J.C. Gianduzzo

Transferred Hyperfine Interactions and Quadrupole Effects for the Diamagnetic Ions in Rare-Earth Elpasolites, $\mathrm{Cs}_{2} \mathrm{NaLnCl}_{6}$. . . . . . . . . . .

F.W. Voss, R. Nevald, G.P. Knudsen, and H.-D. Amberger

Structure-Property Interplay in the System $\mathrm{RTiO}_{3}$ : $\mathrm{R}=$ Lanthanide (III)

J.E. Greedan

Some Magnetic Properties of the System $\mathrm{La}_{x} \mathrm{Gd}_{1-\mathrm{x}} \mathrm{TiO}_{3} \cdot$. . . 441 J.P. Goral and J.E. Greedan

Zero Field Temperature Dependence of the Rare Earth Sublattice Magnetization in $\mathrm{RTiO}_{3} ; \mathrm{R}=\mathrm{Tb}$, Dy, Ho, Er and $\mathrm{Tm}$. . . . . . . . . . . . . .

C.W. Turner, M.F. Collins and J.E. Greedan

Magnetic and Structural Properties of $\mathrm{CeSb}_{1-x} \mathrm{Te}_{\mathbf{x}}$

Mixed Compounds ... . . . . . . . . . . .

D. Ravot, J.C. Achard, J. Rossat-Mignod

Effects of the Non-Stoichiometry on the

Transport Properties of CeSb . . . . . . . . . 451

D. Ravot, J.C. Achard, M. Escorne and A. Mauger

Low-Temperature Behavior of DyS, DySe, HoS and HoSe . . . .

F. Hulliger, M. Landolt and R. Schmelczer

Electrical Resistivity and Magnetic Field Effects

of $\mathrm{NdS}_{3-\mathrm{x}} \mathrm{V}_{\mathrm{X}} \mathrm{S}_{4}$. . . . . . . . . . . . . . . 459

S.M.A. Taher and J.B. Gruber

Faraday Rotation of Rare Earth Alkali Germenate Glasses . • . 465 S.C. Cherukuri and L.D. Pye

\section{HYDRIDES}

Using NMR to Study the Properties of Rare-Earth

Materials Containing Hydrogen. . . . . . . . .

R.G. Barnes

Magnetic and Structural Properties of $\mathrm{Y}_{6} \mathrm{Mn}_{23} \mathrm{D}_{23}$. . . . . .

C. Crowder, B. Kebe, W.J. James and W. Yelon 
Magnetic and Structural Properties of $\mathrm{Th}_{6} \mathrm{Mn}_{23} \mathrm{D}_{\mathrm{X}}$ and $\mathrm{Y}_{6} \mathrm{Mn}_{23} \mathrm{D}_{\mathrm{X}}$. . . . . . . . . . . . . . . . .

K. Hardman, J.J. Rhyne, E. Prince, H.K. Smith, S.K. Malik and W.E. Wallace

Valence Bonding, Atomic Volumes, and Coordination. Numbers for $\mathrm{Y}_{6} \mathrm{Mn}_{23}$, $\mathrm{Th}_{6} \mathrm{Mn}_{23}$, and Their Hydrides . . 479 F.E. Carter

Structure of $\mathrm{Al}, \mathrm{Cu}$ and $\mathrm{Si}$ Substituted $\mathrm{LaNi}_{5}$ and of the Corresponding $\beta$-Deuterides from Powder Neuton Diffraction. Localized Diffusion Mode of Hydrogen in $\mathrm{LaNi}_{5}$ and $\mathrm{Al}$ and Mn Substituted Compounds from Quasielastic Neutron Scattering . . . . . . .

J.C. Achard, A.J. Dianoux, C. Lartigue, A. Percheron-Guegan and F. Tasset

Thermodynamic and Magnetic Properties of $\mathrm{LaNi}_{5-\mathrm{x}} \mathrm{Fe}_{\mathrm{x}}$ Compounds and Their Hydrides . . . . . . . . . . .

J. Lamlouni, C. Lartique, A. Percheron-Guegan, J.C. Achard and G. Jehanno

Thermodynamic Properties of LaNi 4 it Compounds and Their Hydrides . . . . . . . . . . . . . . . . . . .

A. Pasturel, C. Chatillon, A. Percheron-Guegan, and J.C. Achard

Hydrogen Desorption Rates in $\mathrm{LaNi}_{5-\mathrm{x}^{\mathrm{A}} 1_{\mathrm{X}}-\mathrm{H}}$. . . . . . . .

Arthur Tauber and Robert D. Finnegan

\section{PURIFICATION AND ANALYSIS}

Structure-Reactivity Studies on the Extraction of Lanthanides by Dialkyl Isopropylphosphonates . . . .

C. Yuan, W. Ye, E. Ma, F. Wu and X. Yan

Separation of The Rare Earths and Some Polyvalent

Cations on Inorganic Ion Exchangers

J.-K. Cheng, R. Cai, X. Zhao, S. Shi and $\mathrm{Y}$ Tseng

Solvent Extration Behavior of Lanthanides with Di (2-Ethylhexy1) Isopropylphosphonate . . . . . . . .

E. Ma, S. Wang, F. Wu and C. Yuan

Spectrophotometric Determination of Rare Earths

in Ligand Buffer Masking Systems . . . . . . . . . .

J. Cheng, Q. Luo, R. Cai, X. Li and Y. Tseng 
Spectrophotometric Determination of Trace Amounts of

Copper in High-Purity Rare Earth with $\alpha, \beta, \gamma, \delta-$

Tetra-(4-trimethylammonium-pheny1) Porphine

J.Cheng, K. Yang and Q. Chang

Rare Earth Ion Selective Electrodes: II. Europium

and Praseodymium Compound Membranes . . . . . . .

Y. Suzuki, H. Itoh and T. Nakano

Analysis of Rare Earth Elements in Ore Concentrate

Samples using Direct Current Plasma Spectrometry . . .

G.W. Johnson and T.E. Sisneros

Behavior of REE in Geological and Biological Systems . . .

J.C. Laul and W.C. Weimer

\section{NEW APPLICATIONS}

Trends in Rare Earth Metal Consumption for Steel

Applications in the 1980 's . . . . . . . . . . .

J.R. Jackman and W.H. Trethewey

The Use of Rare Earths in Photovoltaics . . . . . . . . .

P. Munz and E. Bucher

Preparing Rare Earth Silicon Iron Alloys . . . . . . . . 557

E. Morrice and M.M. Wong

Catalysis Using Rare Earth and Actinide Intermetallics

Containing $\mathrm{Fe}$, $\mathrm{Co}, \mathrm{Ni}$ and $\mathrm{Cu}$. . . . . . . . . . 561

W.E. Wallace, J. France and A. Shamsi

Electrochemical Corrosion of Lanthanum Chromite

and Yttrium Chromite in Coal Slag . . . . . . . . .

D. D. Marchant and J.L. Bates

AUTHOR INDEX . . . . . . . . . . . . . . . . 577

SUBJECT INDEX . . . . . . . . . . . . . . . . 581 